\title{
QUARTZ SAND USE IN HYDRAULIC AND SANITARY ENGINEERING
}

\section{KREMENOV PESEK V HIDROTEHNIKI IN KOMUNALI}

\author{
Tamara Kuzmanić ${ }^{1},{ }^{*}$, Matjaž Mikoš ${ }^{1}$ \\ ${ }^{1}$ Fakulteta za gradbeništvo in geodezijo, Univerza v Ljubljani, Jamova 2, Ljubljana, Slovenia
}

\begin{abstract}
An overview of the production and usage of quartz sand as a special sort of sand for civil engineering is presented - from the formation of sand deposits, through mining and processing methods, to its final use, with an emphasis on its use in civil engineering, i.e. in water filtration. Quartz is found in sedimentary, metamorphic, and igneous rocks. During sand formation in the fluvial environment, quartz grains are highly resistant to weathering and mechanical wear, and can be transported a long way without changes to size and form. Therefore, quartz is the main constituent of most natural sands. Quartz and quartz sand are ubiquitous raw materials used in a wide range of products in civil engineering due to their chemical inertia and high temperature resistance. An example of a quartz sand deposit and processing plant in Slovenia is presented as a practical case study on quartz sand application. The described applications using quartz sand are the best available technologies in sanitary and hydraulic engineering to be used for a move towards a circular economy, smart houses, and smart cities.
\end{abstract}

Keywords: quartz sand, water treatment, sand filter, green infrastructure, filter media, granular media, granulometry.

\section{Izvleček}

$\mathrm{V}$ prispevku je podan pregled pridobivanja in uporabe kremenovega peska kot posebej zanimive vrste peska za gradbeništvo - od nastanka nahajališč, preko metod rudarjenja in predelave do končne uporabe $\mathrm{v}$ gradbeništvu s poudarkom na uporabi pri filtraciji vode. Kremen je prisoten v sedimentnih, metamorfnih in magmatskih kamninah. Med tvorbo peska v fluvialnem okolju so kremenova zrna zelo odporna na vremenske vplive in mehansko obrabo, njihova velikost in oblika ostajata nespremenjeni tudi po premeščanju na daljše razdalje. Zato je kremen glavna sestavina večine naravnih peskov. Kremen in kremenov pesek sta zaradi svoje kemijske inertnosti in visokotemperaturne odpornosti vseprisotna surovina, ki se uporablja v širokem naboru gradbenih izdelkov. Naveden je primer nahajališča in obrata za predelavo kremenovega peska v Sloveniji kot konkretni primer njegove uporabe. Opisane uporabe kremenovega peska predstavljajo najboljše razpoložljive tehnologije v hidrotehniki in komunali, ki jih moramo uporabiti za prehod v krožno gospodarstvo, pametne hiše in pametna mesta.

Ključne besede: kremenov pesek, čiščenje vode, peščeni filter, zelena infrastruktura, filtrirni mediji, zrnati mediji, zrnavostna sestava.

\footnotetext{
* Stik / Correspondence: tamara.kuzmanic@fgg.uni-lj.si

(C) Kuzmanić T. and Mikoš M.; Vsebina tega članka se sme uporabljati v skladu s pogoji licence Creative Commons Priznanje avtorstva - Nekomercialno - Deljenje pod enakimi pogoji 4.0.
}

(C) Kuzmanić T. and Mikoš M.; This is an open-access article distributed under the terms of the Creative Commons Attribution NonCommercial - ShareAlike 4.0 Licence.

https://doi.org/10.15292/acta.hydro.2020.02 


\section{Introduction}

Aggregates, mainly sand and gravel, are the most consumed natural resource after water, making up the largest portion of mined raw materials. It is estimated that globally up to $50 \mathrm{Gt}$ of aggregates are mined per year (Peduzzi, 2014; UNEP, 2019; Torres et al., 2017; GAIN, n.d.). Average consumption of aggregates per person is around $18 \mathrm{~kg}$ per day, which add up to over 6 tonnes a year (OECD 2016; GAIN n.d.). According to UNEP (2019) the demand for aggregates will rise up to $60 \mathrm{Gt} /$ year by 2030 , and according to OECD (2019) up to 86 Gt/year by 2060.

Sand is a granular material, with a grain size range within the limits of $2.0 \mathrm{~mm}$ and $0.0625(1 / 16 \mathrm{~mm})$. It can be further classified according to size (i.e. fine and coarse sand) and according to mineral composition (i.e. quartz sand and carbonate sand) (Vrkljan, 2011; Pettijohn et al., 1973). Quartz $\left(\mathrm{SiO}_{2}\right)$ is one of the most abundant minerals in Earth's crust, comprising over 12\% (by weight) of the Earth's crust. It is present as a sedimentary, metamorphic, and igneous rock (Götze and Möckel, 2012). Quartz sands are used for manufacturing of glass, optical glass, castings and forms, for production of refractory materials, as granular media in water treatment, and for manufacturing of cement, brick and concrete. Quartz sands are also used to produce silicon carbide, fireproof materials, and abrasives (Götze and Möckel, 2012; Vrkljan, 2011; Pettijohn et al., 1973). Naturally occurring quartz can be either monocrystalline (i.e. a single crystal) or polycrystalline (i.e. in a rock form) (Götze, 2009; Pettijohn et al., 1973). Sand can be found in and mined from different types of deposits. It occurs as a deposit in river channels, floodplains, lakes, and reservoirs. Sand forms lots of beaches, but mining such sand is often prohibited, as it protects land from coastal erosion. It is present in dunes and glacial outwash (Padmalal and Maya, 2014). Most sand deposits contain a portion of quartz, with those sand from deposits containing a high portion of quartz ( $>95 \%$ ) being referred to as quartz sand (orthoquartzite) or industrial sands (Pettijohn et al., 1973). Quartz sand appearance reflects its mineral composition and can indicate the presence of impurities. Pure quartz sand tends to be white, very light grey, or yellow. Grey colour indicates the presence of clay and rock fragments, while red and brown indicate the presence of iron minerals, which often occur in the form of coatings on the quartz grains.

Quartz sand originates from disintegration, i.e. weathering and wearing of quartz containing rocks (igneous, metamorphic and sedimentary), such as granite, sandstone (quartz arenites), quartzite, etc. (Vrkljan, 2011; Padmalal and Maya, 2014). This lithic weathering is part of the erosionsedimentation cycle, by which rocks are fragmented, transported, and deposited. During transportation, loosened and detached rock fragments and grains are subjected to mechanical and chemical weathering and abrasion, which change their size and properties. During transport, particles lose weaker and soluble minerals, and they become more rounded and smaller. Detached particles are primarily transported by water flow (Platias et al., 2014). In the fluvial environment, rock fragment particles are exposed to wear. All of those processes produce clay, silt and sand-sized particles. Some particles roll and slide along the bed, which results in wearing (abrasion and attrition), while others saltate and promote breakage between colliding particles. During rolling and sliding, angular corners are worn off from particles and they become more rounded and smaller. The weathering includes actions such as changes in temperature, freezing and thawing (frost action), and hydration of rock fragments and mineral grains. During weathering and wearing (abrasion) processes, some softer minerals may be completely lost (to mud and silt sizes), while others (e.g. quartz) can be transported unchanged for significant distances.

This paper consists of three major parts. In the first part, the characteristics of quartz sand are presented. In addition, the exploitation of quartz sand, including both the mining/excavation and processing of material, is described. The second part of the paper contains an overview of existing applications in water treatment technologies and processes. Last but not least, the current situation in using quartz sand in Slovenia is presented, with a special emphasis on the study results of quartz sand 
characteristics obtained at the Ravno plant in Novo Mesto.

Slovenia is considered a pioneer in recycling. In 2018 Slovenia recycled $58.9 \%$ of municipal waste, and in 2016 Slovenia recycled 80\% of all waste (excluding major mineral wastes), with only $5 \%$ of waste ending up in a landfill (Eurostat, 2020a; Eurostat, 2020b; Eurostat, 2020c). From this point, further development and progress in water cycling would be a step towards the goals set by the EU Commission in Circular Economy Action Plan i.e. EU Green Deal (EU, 2020). As an alternative water resource, water reuse has versatile benefits, such as keeping fresh water for drinking and reclaimed for non-drinking uses, reducing nutrient loads to receiving waters, environmental protection, increased agriculture (consequently economy and employment), etc. (EU, 2015).

\section{Sand exploitation}

Most raw material used for commercial purposes must be mined (extracted) and then processed to some extent. Exploitation includes both the mining/excavation and processing of material extracted from the deposit. Raw materials can be mined and later used in their natural form (mineral sand, gravel, clay, etc.) or can be mined and used as a crushed rock (produced by crushing of mined rock). The schematic representation of sand exploitation from deposit to final products is shown in Figure 1.

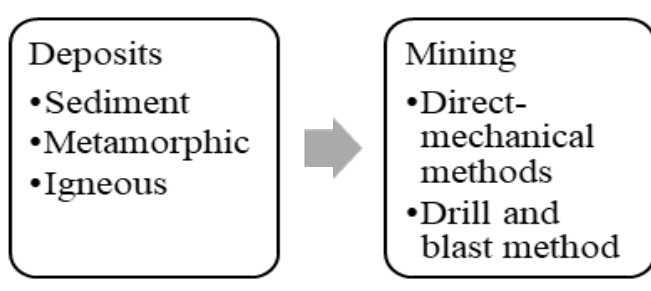

Figure 1: Block diagram of sand exploitation.

Slika 1: Diagram pridobivanja peska.

\subsection{Sand mining}

Sand can be mined using various, mostly surface, methods in open-pit mines or quarries. Underground mining is avoided because of unconsolidated and soft deposits. Quartz sand can be mined with a front-end loader, diesel shovel, scrapers, rippers, dozers, or similar equipment. Material is directly excavated from the deposits and loaded to transport for processing. When quartz is in rock form and the rock is hard, it can be mined using the drill and blast method, whereas quartz can be mined directly (using shovels, loaders, etc.) when the parent rock is fragmented. If the deposit is below the water table or in the water body, draglines and dredging boats are used to excavate the material from below the water surface. Methods used for sand mining include (i) bar scalping or skimming sand is excavated directly from the surface of bars, (ii) channel mining - the material is excavated from the dry intermittent stream beds or active channels, (iii) marine mining - excavation from offshore areas, (iv) terrace pit mining and floodplain mining, and (v) instream - using bedload traps or cross section dredging (Padmalal and Maya, 2014; Kennedy, 2009; DID, 2009; EBRD, n.a.).

Sand should be mined with respect for natural regimes, avoiding instream mining and preferentially mine deposits outside active streams (older fluvial deposits). Mining in an active stream has negative impact on the water regime inside river, which is why it is prohibited in many countries. Once mining at the site is finished, the mining area has to be revitalised and

\begin{tabular}{|l|l|}
\hline $\begin{array}{l}\text { Processing } \\
\text { - Washing and } \\
\text { classification } \\
\text { - Attrition } \\
\text { scrubbing } \\
\text { - Magnetic and } \\
\text { electrostatic } \\
\text { concentration } \\
\text { - Gravity } \\
\text { concentration } \\
\text { - Flotation }\end{array}$ & \begin{tabular}{l} 
Final products \\
$\bullet$ Glass sand \\
\hline
\end{tabular} \\
\hline
\end{tabular}


secured. This revitalisation should be carried out so as to support the area's revegetation and help fauna reinhabit it. Sometimes, the revitalization of former mining sites can be repurposed to recreational areas (e.g. artificial lakes, sport areas, etc.).

\subsection{Sand processing}

Quartz sand found in deposits usually does not meet the requirements set by the industries that use it. This is especially true for the quartz sand pits where the best-quality sand has already been exploited. Therefore, raw quartz sand excavated at deposits must undergo certain processes to improve its properties, such as the particle size distribution, chemical composition, and water content. Those processes can be physical or chemical, depending on what principal they separate the wanted (concentrate) from unwanted (tailings) portion of material. The applicability of the methods to be used for sand processing depends on the properties of raw sand.

Sand should be processed with as little energy input and as little chemical presence possible in the process to achieve desired quality. In addition to a smaller environmental impact, such an approach is also more affordable. The process selection and design are specific for each deposit.

\subsubsection{Washing and classification}

Most of the quartz sand deposits contain a portion of clay $(-0.0625 \mathrm{~mm})$ content and a portion of too coarse material $(+2 \mathrm{~mm}-$ gravel $)$ in the raw material. At the beginning of processing, the material is usually washed to loosen the clay and remove potential organic matter (e.g. wood or plant residuals). The material can be washed in the trommel screen, where particles smaller than the screen openings continue through the process further, whereas bigger particles are removed from the process. Clay and too fine material is later removed from the process by hydro-cyclones, cyclones, spiral classifiers, screens, and other equipment that uses similar mechanisms to separate fine from coarser particles (Finch and Wills, 2016; Fuerstenau and Han, 2003).

\subsubsection{Attrition scrubbing}

Attrition scrubbing/cleaning uses abrasion to remove metal oxide coatings from the surface of quartz sand grains. Motions inside the attrition cells are introduced to the sand and water suspension via rotating impellers. Sand grains scrub against each other, which removes coatings from the grain surfaces due to abrasion. After attrition, metal oxides remain in the slurry as very fine particles, which are later removed in the same manner as the clay content (Finch and Wills, 2016).

If metal oxides are present as heavy mineral grains, further processing steps are needed for their removal.

\subsubsection{Magnetic and electrostatic concentration}

Magnetic and electrostatic concentration can be used to separate mineral grains that show magnetic properties from the material. In quartz sand processing it can be used to extract magnetic minerals (e.g. as magnetite from quartz sand grains) (Finch and Wills, 2016; Fuerstenau and Han, 2003).

\subsubsection{Flotation}

Flotation (floatation) is a chemical process for mineral concentration. It is based on differences in components' (concentrate and tailings) buoyancy. For efficient flotation, the material must be fine enough so that water bubbles can lift it to froth. Flotation is performed in the presence of various organic and inorganic chemicals that modify the buoyancy of targeted minerals in order to stimulate floating or sinking according to needs (Gupta and Yan, 2016; Finch and Wills, 2016; Pryor, 1965).

Lately, many mining companies have been turning away from flotation and instead implementing gravity concentration. Compared to flotation, gravity concentration is a much simpler and more economical process. Moreover, due to the absence of chemicals, less environmental impact is expected (Gupta and Yan, 2016). 


\subsubsection{Gravity concentration - Humphrey's spiral and Shaking table}

Gravity concentration uses differences in specific gravities between concentrate and tailings to separate feed material. The difference between those specific gravities (densities) must be significant for separation to be efficient. The efficiency of concentration is higher with a narrower feed particle size range (Pryor, 1965; Gupta and Yan, 2016).

Most commonly, Humphrey's spirals are used (Figure 2a). Humphrey's spiral is a piece of equipment consisting of 4-5 spiral segments (curves). A suspension of quartz sand (feed material) and water is introduced at the top of the spiral and gravitationally flows towards the bottom. The separation appears due to the combination of gravitational, centrifugal, and hydrodynamic forces. Heavier (and coarser) particles move closer to the inner radius of the spiral, while lighter (and finer) particles move closer to the spiral's outer radius (Pryor, 1965; Finch and Wills, 2016; Gupta and Yan, 2016).

light minerals

heavy minerals

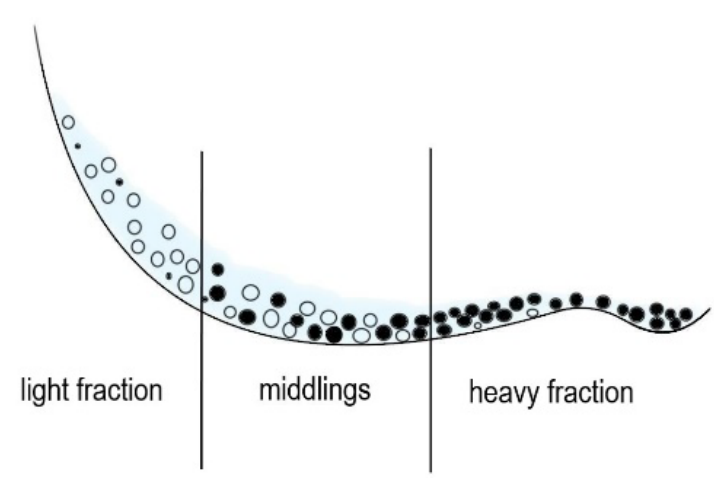

Figure 2a: Humphrey's spiral scheme.

Slika 2a: Shematski prikaz Humphreyjeve spirale.

Shaking tables can also be used to process quartz sand (Figure 2b). Shaking tables are slightly inclined panels with channels on top of them and an eccentric drive, which moves the table longitudinally. The quartz sand and water suspension is introduced at the top of the table and is spread across the table. Due to the table motions and water flow, the feed material is separated, with heavier particles moving further across the table longitudinally and lighter ones moving shorter distances across the table (Finch and Wills, 2016; Pryor, 1965; Fuerstenau and Han, 2003).

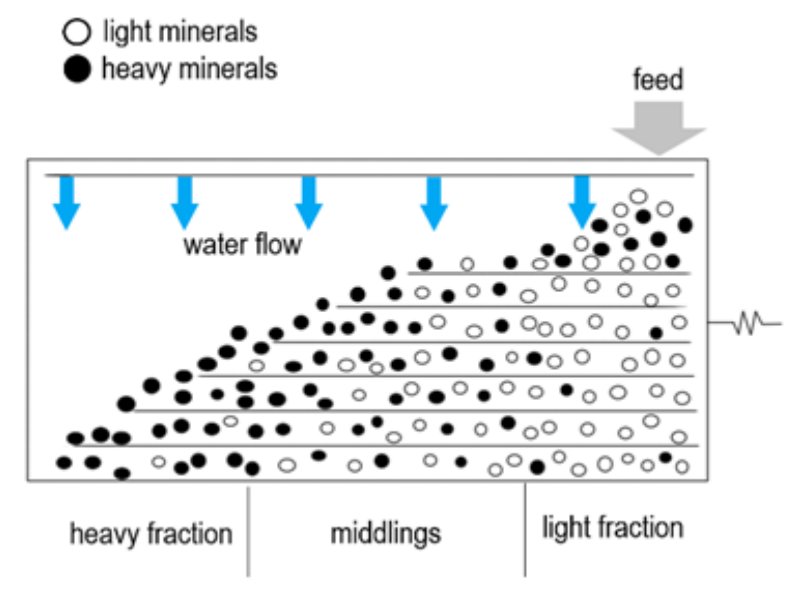

Figure 2b: Shacking table scheme.

Slika 2b: Shematski prikaz stresalne mize.

\subsection{Life Cycle Assessment}

Life Cycle Assessment (LCA) is the process of systemizing and evaluating inputs, outputs and potential environmental impacts of a product (or process) through its life cycle (Curran, 2012). A life cycle begins with energy generation and raw materials extraction (mining), which later become part of manufacturing, transportation and use until they are disposed (or recycled) (UNEP, 2004). The LCA includes all phases needed to manufacture a product, and evaluates the environmental impact of the complete cycle (RIVM, 2016). The life cycle impact assessment (LCIA) helps in the interpretation of LCA by assigning environmental impact scores in an "impact profile", which is a list with various environmental effects, e.g. climate change, water use, land use, etc. "Impact profile" gives an insight into the phases of the life cycle that contribute the most to the environmental effects (RIVM, 2016). LCA and LCIA allow for the offset of negative and positive impacts on the economy, environment, and society (UNEP, 2004). The mining industry has often been a centre of interest as the source of the most impacts in the product cycle, based on the LCA processes can be optimized and turned to more sustainable ones (Currian, 2012; RIVM, 2016). 
Grbeš (2016) conducted an LCA of three types of methods used for quartz sand mineral processing, namely electrostatic separation, flotation, and gravity concentration. Basic processing procedures (washing and sizing) showed the smallest impact, but those are insufficient for high-grade sand. More complex processing methods cause polluting chemical emissions due to the use of fuels and reagents. Environmental impacts are caused by consumption of fossil fuels, electricity, water, and chemicals, with the major contributor shown to be fossil fuel use (Grbeš, 2016). Similar conclusions can be found in Ferreira and Leite (2015), who conducted an LCA of iron ore mining and concluded that fossil fuel consumption accounted for $36 \%$ of the total impact.

Reusing and recycling products and materials reduces environmental impacts due to prolonged use and prevention from going to waste. Quartz sand, being inert and durable, is recyclable, and new products can be made from it. As an example, glass (consisting of more than $70 \% \mathrm{SiO}_{2}$ ) can be recycled indefinitely without quality loss. According to the British Geological Survey (2020), every ton of recycled glass saves $250 \mathrm{~kg}$ of $\mathrm{CO}_{2}$ during manufacturing, as well as 1.2 tons of raw material. Foundry sand can be reclaimed and reused (with the addition of some fresh sand) or can be used in asphalt or cement (BGS, 2020; Balbay, 2019; Borek et al., 2020).

\section{Use of quartz sand}

The term "industrial quartz sand" is used for quartz sand with a specified amount of $\mathrm{SiO}_{2}$ content and particle size distribution (granulometry). Quartz sand is a relatively low-value raw material, but it is broadly used in industrial applications. To be usable for industrial purposes, quartz sand must meet certain requirements set by final users (branches). Those requirements are different for different applications, but most commonly include $\mathrm{SiO}_{2}$ content, particle size distribution, particle range, uniformity, etc. To obtain a higher $\mathrm{SiO}_{2}$ content than that found in nature, quartz sand is subjected to beneficiation processes, which can be either physical or chemical processes. The higher the $\mathrm{SiO}_{2}$ content, the higher the value of the quartz sand is. Different industries have different requirements regarding the properties of quartz sand (Platias et al., 2014).

Quartz is the main component for glass production. Quartz sand for glass manufacturing has the strictest chemical content requirements, as it must be highpurity. Requirements include high $\mathrm{SiO}_{2}$ content and a low presence of heavy minerals (especially iron oxide), because $\mathrm{Fe}_{2} \mathrm{O}_{3}$ inclusions in quartz sand form coloured stains in the final glass product. Quartz sand for glass production is also used in ceramics production. (Platias et al., 2014; Vrkljan, 2011; Samsa, n.a.; Götze, 2009). In foundries, quartz sand is used for castings and forms, along with clays and special resins as binders. Sand used in foundries must have high $\mathrm{SiO}_{2}$ content. Other requirements include restrictions on $\mathrm{CaO}$ and $\mathrm{MgO}$ content, thermal stability and specific particle size distribution, which can assure sufficient permeability for gasses to exit (Vrkljan, 2011; Samsa, n.a.; Götze, 2009). Quartz sand is used in foundries, when it physically degrades, it is discarded and should be recycled if possible. Bradshaw et al. (2011) reported about the recycling of foundry quartz (silica) sands in the USA for engineering applications in the construction industry, i.e. for green infrastructure construction: Portland cement concrete, hot mix asphalt, road subbase layers, embankments, and flowable fill. Annual production in the USA was at that time around 100 million tons, and annually 9 to 10 million tons were discarded. Recycling of foundry sands can save energy and costs, and reduce the need to mine virgin materials, all in the sense of the circular economy and reducing the construction industry's carbon footprint.

Since quartz sand is stable and inert, it is used as a filler in numerous industries, such as in paint and coating production, special cements (high resistance to acids), varnishes, etc. It is used as a filler to improve the physical properties of final products, e.g. durability, thermal properties, resistance, and shine. For such uses, the sand must be white (Platias et al., 2014; Vrkljan, 2011). The degree of abrasiveness and the sand grain size determine the application of quartz sand as abrasive. It can be used 
to clean steel constructions and strip coatings, polish marble, polish and clean softer alloys, and clean denim in the textile industry. Quartz sand is also used in the gas and petroleum industry, such as in proppants (frac sand) to keep cracks in drill hole opened to assure flow. It is also used in fireproof material manufacturing, as a main raw material for glass-wool production and special concrete production. (Padmalal and Maya, 2014; Vrkljan, 2011; Samsa, n.a.). It has also long been used in water treatment as one of the prime methods for water filtration, due to its' simplicity and availability. For filtration purposes it is used in water supply systems and in wastewater and technological water management. In the same light, quartz sand could play a role in the reuse and recycling of water.

\subsection{Filtration sand}

Most of the water supplied to the public system must be pre-treated using various mechanical and chemical processes, including filtration. The same as supplied water, used water must be treated before being reused or released into natural water bodies. Filters can generally be divided into two groups, based on the mode of filtration action: deep-bed filters and surface filters. Surface filters use fabric or a membrane that permits water through, but retains particulate material. Deep-bed filters consist of granular media that retains particulate material as the water flows through it. Many different types of deep-bed (granular) filters are available, but generally they can be divided into rapid sand filters and slow sand filters. Slow sand filters develop a coating of biological film on the upper layer of granular material and thus the filtration process greatly relies on biological activity. Rapid sand filters rely solely on physical removal through the depth of filtering media (Casey, 2006; WHO, 2002). Filtration takes place due to the (i) straining (when particles or organisms are too big to pass between filter bed grains), (ii) attachment (when particles or organisms attach to the filter bed grains as they pass through the bed) (Logsdon, 2008). Although ultrafiltration processes have begun replacing granular bed filtration, it is still widely used in developing countries. As a filter media in granular bed filtration, quartz sand, anthracite coal, granular activated carbon (GAC), high-density material (hematite, magnetite, ilmenite), and manufactured granular media are used (Logsdon, 2008). Problems in granular filters include filter bed growth, short run, and insufficient filtration. Those can be caused by the filter clogging and subsequent accumulation of particulate matter in the filter bed, algal bloom in the filter, and inefficient backwashing (Tatari, 2014; Lopato 2011). Poor washing of rapid sand filters results in the floc build up and deposition of algal and detrital matter, leading to cracking and shrinkage of the filter bed. Slow sand filters are not suitable for the removal of fine inorganic suspended matter, while high concentrations of algae in treated water can cause filters to clog. Due to the filter clogging, organisms die off in the filter and impart their taste into the water (Brandt et al, 2017).

As a filter media in ultrafiltration processes, diverse polymer membranes and ceramic membranes are used. Membrane filtration (including ultrafiltration) does not require physiochemical conditioning for removing small particles (e.g. coagulant addition prior to the filtration), and can directly be applied on raw water with a prefiltration stage to reduce particle range (Brandt et al., 2017).

Quartz sand (or silica sand) is prominent as a filtration medium due to its chemical inertia and high-temperature resistance. For quartz sand to be used as a filtration medium in granular filters for drinking water treatment, they must have properties according to the standard BS EN 12904:2005 "Products used for treatment of water intended for human consumption - silica sand and silica gravel”.

The coefficient of uniformity, particle size distribution, granular media density, and chemical composition are normalized. The coefficient of uniformity $\left(\mathrm{C}_{\mathrm{u}}\right)$ should not exceed 1.5. Various studies have shown differing values. Logsdon (2008) quotes the typical effective size $\left(D_{10}\right)$ 0.45$0.7 \mathrm{~mm}$ and the range of the coefficient of uniformity being between 1.4 and 1.5 .

As proposed by Brandt et al. (2017), quartz sand can be used in high-rate clarifiers during drinking water treatment as a ballasting agent to form a weighted floc of density in excess of $2.5 \mathrm{~kg} / \mathrm{l}$, resulting in high 
settling velocities. Usually, fine grained quartz sand is applied ( $D_{10}$ of $100-150 \mu \mathrm{m}$ and uniformity coefficient of 1.6).

On the other hand, Panjan (2002) states that the allowed diameters of grains are within 0.7-2.0 mm. According to Casey (2006), sand's effective size should be between 0.15 and $0.30 \mathrm{~mm}$ in order to be used for slow sand filtration, and between 0.6 and $1.2 \mathrm{~mm}$ to be used for rapid sand filtration. Similar numbers can be found in ITACA (2005), where it is stated that $D_{10}$ of sand should be between 0.15 and 0.35 , with $C_{u}$ of $1.5-3$ to be used for slow sand filtration. Another value mentioned by WHO (2002) is $\mathrm{D}$ (particle diameter) of 0.2-0.5 mm for slow sand filtration. As stated by Stephenson (1998), sand grain size should be in the range of $0.4-1.2 \mathrm{~mm}$ for rapid sand filtration. The norm requires $\mathrm{SiO}_{2}$ content to be at least $96 \%$, with maximum content of $\mathrm{Fe}_{2} \mathrm{O}_{3}, \mathrm{Al}_{2} \mathrm{O}_{3}, \mathrm{~K}_{2} \mathrm{O}, \mathrm{Na}_{2} \mathrm{O}$, and $\mathrm{CaO}$ being $2 \%$, $3 \%, 2 \%, 1.5 \%$, and $1.5 \%$, respectively. If granular filters are not intended for drinking water, requirements are not as strict as in the first case. Still, lower values of the coefficient of uniformity are preferable to prevent clogging of the filter.

According to Brandt et al. (2017) quartz sand used in rapid sand filtration should have $\mathrm{C}_{\mathrm{U}}$ less than 1.6 and is usually between 1.3 and 1.5. Quartz sand used in slow sand filtration has $\mathrm{D}_{10}$ in the range 0.21 $2.36 \mathrm{~mm}$ and $\mathrm{C}_{\mathrm{u}}$ between 1.5 and 3.5, but preferably less than 2. Sparks and Chase (2016) quote $C_{u}$ up to 1.75 , with the sand size range of $0.35-0.5 \mathrm{~mm}$ for slow sand filtration. For use in rapid sand filters $C_{u}$ should be up to 1.7 and its size range between 0.5 and $0.6 \mathrm{~mm}$ (Sparks and Chase, 2016). It should be mentioned that media specification cannot be generally applied to all water filters of the same type. The choice of the material depends on water quality, the use of the water after filtration, other processes (before and/or after the filtration), and filter operating parameters (Brandt et al., 2017).

The main mechanism contributing to the removal of total suspended solids in intermittent sand filters is straining, where particles larger than the pores between granular media get wedged (Prochaska and Zouboulis, 2003). Moreover, a Scanning Electron Microscope (SEM) analysis, conducted within the mentioned study, showed that microorganisms on sand grains decreased in size with the depth of the sand bed. The sand used as a filtration medium had an effective size $\mathrm{D}_{10}$ of $0.3 \mathrm{~mm}$ and the coefficient of uniformity $\mathrm{C}_{\mathrm{u}} 2.65$.

Wang et al. (2014) studied the influence of the particle size of quartz sands between 27 and $351 \mu \mathrm{m}$ on the adsorption-desorption characteristics of $\mathrm{E}$. coli by soil. They have found that quartz sands had great adsorption quantity of E. coli (well over 90\%) and small desorption ratio of E. coli (less than 5\%), in both cases this ratio was a function of the particle size; smaller particle sizes had a higher absorption and lower desorption ratio.

Abdel-Shafy et al. (2014) conducted a series of experiments on different sand filters, with sand (1-2 $\mathrm{mm}$ ) and gravel (2-4) as a filtration medium for secondary greywater treatment. From all of the designs tested, the horizontal flow sand filter and gravel filter, followed by the sand filter, proved most efficient. Other designs tested were: gravel filter down flow, gravel filter up flow and sand filter down flow.

Deep bed filtration is commonly used to remove oil from oily wastewater; Liu et al. (2018) proposed that the superhydrophobic quartz sand filter media can potentially be used to filter oily wastewater and achieve high oil removal efficiency.

According to Jenkins et al. (2011), who conducted a study on the efficiency of intermittent slow sand filters, sand-size tends to be the most important factor in slow sand filtration efficiency. Additionally, fine sand provides a higher level of bacteria and virus removal.

In an experimental filter design (Jenkins et al., 2011), a single layer of sand was used to represent the practice used in developing countries. Two types of river sand were used in the study, fine sand and coarse sand, with $\mathrm{D}_{10}$ of $0.17 \mathrm{~mm}$ and $0.52 \mathrm{~mm}$; and $\mathrm{C}_{\mathrm{u}}$ of 2.4 and 2.1, respectively.

Recently, ultrafiltration has come into use and a lot of water treatment plants have switched from granular-media filters to membrane ultrafiltration. Production of ceramic microfiltration membranes made of quartz sand has drawn attention among researchers due to its availability and low cost. 
Aloulou et al. (2017) ran a study on microfiltration membranes from Tunisian natural sand, with the average particle sizes of $100 \mu \mathrm{m}$ (for tubular support) and less than $50 \mu \mathrm{m}$ for microfiltration layers. The average $\mathrm{SiO}_{2}$ content was around 95.09\% for filtration film.

Ivanets and Agabekov (2017) used quartz sand in sizes 200-630 $\mu \mathrm{m}$ for ceramic supports, and 40-70 and 1-40 $\mu \mathrm{m}$ for microfiltration layers. Ivanets and Agabekov (2016) also found that the presence of carbonate compounds causes a decrease in membranes' mechanical properties.

\subsection{Green infrastructure}

Green infrastructure is a network of man-made and natural systems with a wide range of overall benefits. Generally, it absorbs pollutants, reduces temperatures, provides green surfaces in urban areas, acts as a filter for water recovery, etc. (Teemusk and Mander, 2011). Media used for green infrastructure construction are often similar to the media used in granular bed filters (quartz sand or GAC), therefore it enables water filtration. When used for water (and wastewater) filtration, green infrastructure is compliant with the principles of conventional water filtration. Wastewater reuse is identified as one of the priorities of the European Innovation Partnership on Water, as it provides social, environmental, and economic benefits. Those include increased water availability, sustainable use of water resources, increased agricultural production, reduced application of fertilisers, restoration of streams and ponds, etc. Recycled water can be used in a broad range of applications, only some of them are irrigation in agricultural uses, irrigation of public green surfaces and private gardens, fire protection systems, toilet flushing, as processing and cooling water in industry, etc. (EU, 2015).

Recently, green infrastructure's potential to treat greywater for reuse (for example in irrigation or as a lavatory flush water) has become a subject of interest. Greywater is wastewater produced in households, excluding flushed toilet water. It can be further divided into (i) light greywater, which comes from baths and showers, and (ii) dark greywater, which comes from kitchen sinks and dishwashers (Forward et al., 2017; Boano et al., 2020, Hoffmann et al., 2011). Reusing greywater in irrigation and agriculture could provide nutrients to the soil (Boano et al., 2020; Teemusk and Mander, 2011).

\subsubsection{Constructed wetlands}

Constructed wetlands are low-level technology that can be used for wastewater, surface water, and groundwater treatment. Constructed wetlands can be categorized according to the flow direction and flow regime into subsurface horizontal flow, subsurface vertical flow, and free surface constructed wetlands (Maiga et al., 2017; Hoffmann et al., 2011). However, as constructed wetlands require a considerable amount of space, they are not appropriate for urban areas (Foward et al., 2017).

As stated in Boano et al. (2020), the main processes to remove pollutants are adsorption and mechanical filtration, which are closely related to the bed material. Mechanical filtration's capacity for removing pathogens mainly depends on the filter bed, which consists of sand and plant roots (Maiga et al., 2017; Hoffmann et al., 2011). Similarly, Torrens et al. (2009) concluded, that if the particle size distribution is suitable, there is no significant difference between the efficiency of different types of sand.

More and more often, different construction materials are used as wetlands media instead of commonly used gravel: construction solid waste (concrete, coal ash) (Yang et al., 2012), recycled brick (5-10 mm) (Saeed et al., 2018), or crushed cement mortar (Saeed et al., 2019). Such an approach is in line with worldwide circular economy efforts. For wastewater purification, biochar made out of different straw material is widely used in China as constructed wetlands substrate (Wang et al., 2020). As an effective substrate material for subsurface-flow constructed wetlands to remove nitrogen and phosphorus from wastewater sand, gravel or stones can be used, the use of quartz sand is reported by Shen et al. (2019) and Chen and Zhang (2019).

According to Hoffmann et al. (2011), coarse sand is the most suitable filtration medium for subsurface 
flow constructed wetlands. Furthermore, the efficiency grain size $\mathrm{D}_{10}$ of the granular medium should be between 0.1 and $0.4 \mathrm{~mm}$, and smaller uniformity coefficients are preferred.

\subsubsection{Green roofs and green walls}

Green roofs and green walls function similar to wetlands, but they require a smaller amount of space (especially green walls). Green roofs and walls purify runoff water by absorbing and filtering pollutants. The quality of the outflux depends on the thickness and the structure of the filtering substrate layer, and on the present vegetation (Teemusk and Mander, 2011; Forward et al., 2017). When green walls are fixed vertically on the wall of the building (in order to reduce the load on the building), they preferably have lightweight medium as a substrate (Prodanovic et al., 2017). On the other hand, green walls can be built as plants growing upward from the filter, with an example of such a green wall being placed near a building to support vegetation that grows up and alongside the building's façade (Forward et al., 2017). The green wall proposed by Forward et al. (2017) showed the possibility to reduce suspended solids, organics, and nutrients from greywater applied to it. Green roofs could contribute to the rainwater runoff quality due to absorption and filtering pollutants from it. The grade of runoff water purification mostly depends on the properties of the roof, such as composition and thickness of the substrate layer, vegetation, and type of drainage (Teemusk and Mander, 2011). According to Boano et al. (2020), the most important factor is the type of the substrate used.

\section{Quartz sand exploitation in Slovenia}

\subsection{Mineral resources in Slovenia}

Slovenia has numerous mineral ore deposits due to its geological composition. In 2018, there were 10 licensed research and 192 licensed mineral extraction areas in Slovenia (Geološki zavod Slovenije, 2019a), with their overviews being published annually in a periodical entitled "Mineralne Surovine” (“Mineral Resources”).

The distribution of extraction areas in Slovenia can be seen on a map in scale 1:500,000 (Geološki zavod Slovenije, 2019b). In 2018, for quartz sands there were 7 extraction areas (Figure 3).

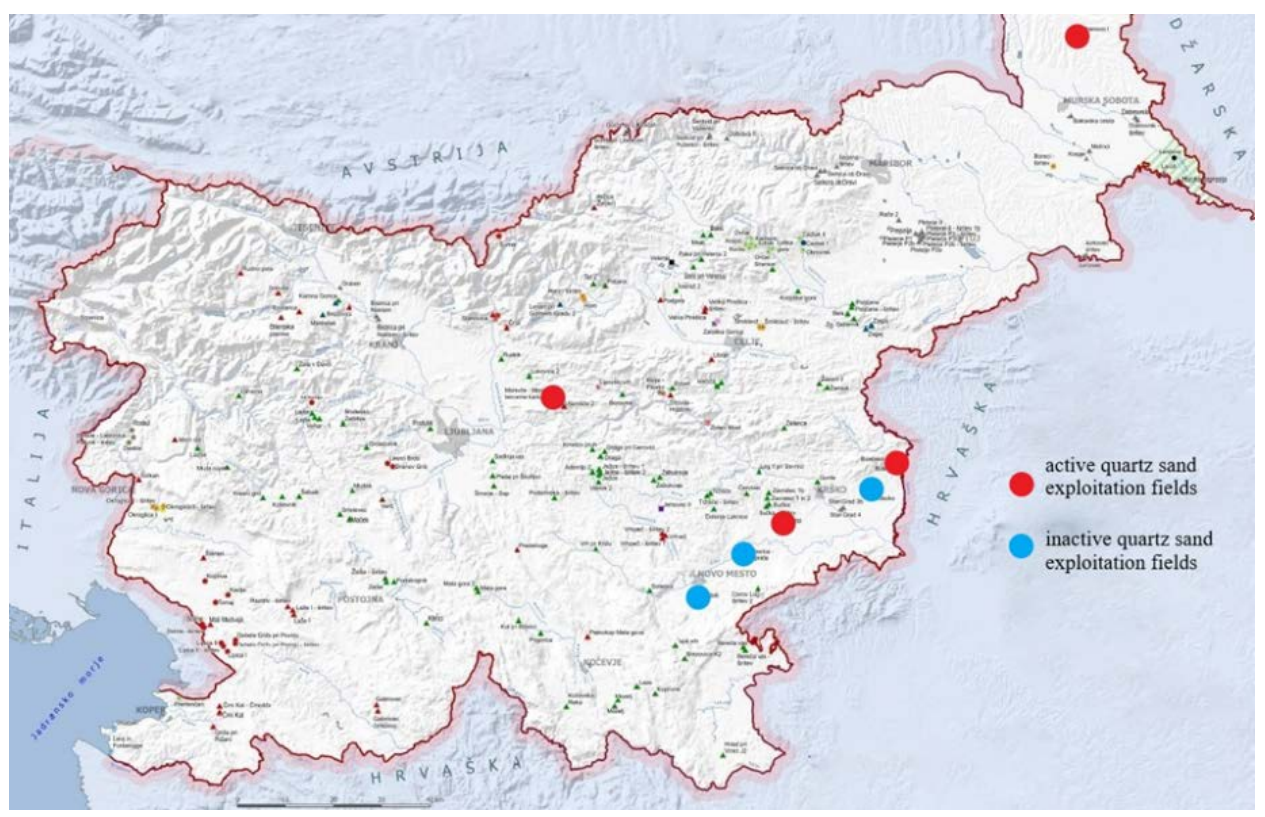

Figure 3: Map of active (red) and inactive (blue) licensed quartz sand exploitations fields in Slovenia in 2018 (Geološki zavod Slovenije, 2019a).

Slika 3: Karta aktivnih (rdeče) in neaktivnih (modra) mest pridobivanja kremenovega peska $v$ Sloveniji s koncesijo v letu 2018 (Geološki zavod Slovenije, 2019a). 
According to Drovenik et al. (1980), sands in Slovenia are found mainly in the eastern part of the country, with quartz sands being mainly of Miocene origin. Out of 7 areas, four quartz sand deposits are being actively exploited in Slovenia (Geological Survey of Slovenia, 2019a). Figure 3 shows the locations of registered exploitation fields of quartz sand, with fields being actively exploited marked with red dots and inactive quartz sand fields marked with blue dots. In 2018, 343,683 tons of quartz sand were exploited, with balance reserves of 14,696,229 tons. Most of the exploited quartz sand is intended for the metallurgical and construction industries (Geological Survey of Slovenia, 2019). As the quartz sand is a raw material with relatively low added value, the price of transportation can be higher than the price of material itself (if transported over longer distances). Therefore, using local reserves lowers local industries' carbon footprints and increases competitiveness, which is also beneficial for the domestic market and economy.

Mikoš (2017) studied fluvial sediments and their use as mineral construction aggregates in Slovenia - he stated that fluvial sands are only a minor part of the total annual amounts of sand mined in Slovenia: in 2011-2015 in total 1.5 million m3 of fluvial sediments were dredged and the total mined amounts of sands and gravels were 11.5 million tons. Thus, mining of virgin natural sands is limited, which is also true for quartz sands, and, therefore, recycling of used quartz sands is the way to go.

As an example of quartz sand deposit and exploitation site in Slovenia, the active deposit "Ravno" is presented in the following section.

\subsection{Quartz sand from the "Ravno" deposit}

The quartz sand deposit "Ravno" is located in the Dolenjska region and occupies an area of $1.25 \mathrm{~km}^{2}$. The exploitation area of the Ravno deposit is shown in Figure 4. In the 90s the exploitable quartz sand reserves at the deposit were determined to be $3,543,048$ tons and with another 1,500,000 $\mathrm{m}^{3}$ of potential ones (with current exploitation rights ending in 2021) (Žmavčič, 1991; Rudarska knjiga, 2020), with annual production of around 125,000 tons. With the prolongation of the concession, current reserves have to be determined. Quartz sand layer is made from yellow and red to brownish sand. Most of the heavy minerals present are biotite, titanite, tourmaline, magnetite, hematite, ilmenite and zirconium. Quartz sand at the location is selective-mechanically surface mined, using shovel baggers and dozers. After excavation, sand is transported to the mineral processing plant nearby the deposit. At the processing plant, quartz sand is washed and undergoes attrition. Clay content and heavy minerals coatings scrubbed with attrition are eliminated in a system of hydro-cyclones and hydro-classifiers. At this point, one of the final products is separated with additional classifying, i.e. washed sand (Rp). The rest of the material goes to the flotation process, where in the presence of reagents in flotation cells heavy minerals are floated and removed, with the concentrate sand representing the other final product (RstF) (Žmavčič, 1991).

At the processing plant, the potential of replacing flotation process with gravity separation is being investigated. The potential alteration of the process would reduce impact to the environment due to the absence of chemicals involved in process and lower energy inputs per ton of final product, which could also reduce expenses per ton (Kuzmanić, 2018).

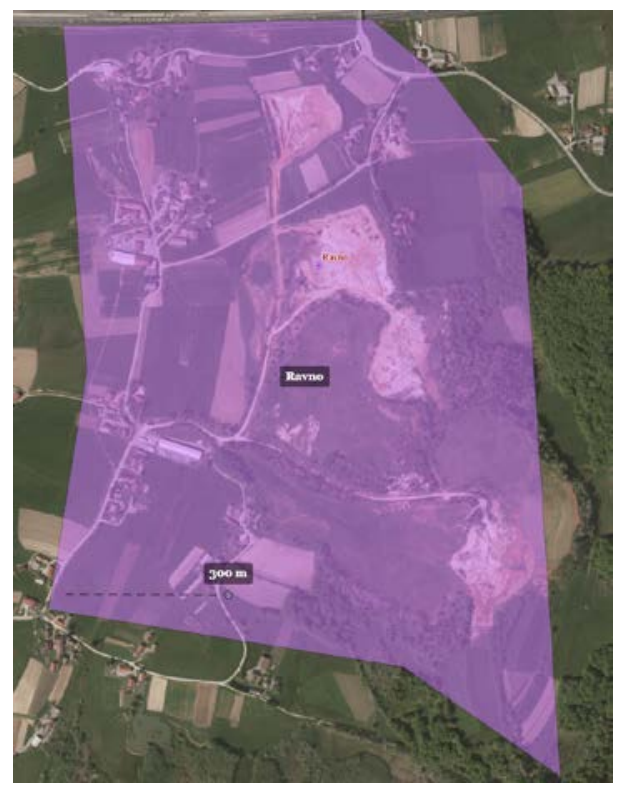

Figure 4: Exploitation area "Ravno" (Rudarska Knjiga, 2020).

Slika 4: Območje peskokopa »Ravno« (Rudarska Knjiga, 2020). 
Near the Ravno deposit there is another deposit with a much smaller exploitation quantity called "Prapreče", which is currently inactive. While the mining works were active at Prapreče, coarser quartz sand P1, P2, P3, and P4 in fractions of $1 / 0$ $\mathrm{mm}, 2 / 1 \mathrm{~mm}, 3 / 2 \mathrm{~mm}$, and $6 / 3 \mathrm{~mm}$ respectively were excavated. Chemical composition of final products from the Ravno and Prapreče deposits is shown in Table 1.

Table 1: Chemical composition - Rp, RstF, and P.

Preglednica 1: Kemijska sestava - Rp, RstF in P.

\begin{tabular}{cccc}
\hline$\%$ & $\mathrm{Rp}$ & $\mathrm{RstF}$ & $\mathrm{P}(1-4)$ \\
\hline $\mathrm{SiO}_{2}$ & $>97.0$ & $>99.0$ & $>99.0$ \\
$\mathrm{Fe}_{2} \mathrm{O}_{3}$ & $<0.35$ & $<0.08$ & $<0.12$ \\
$\mathrm{Al}_{2} \mathrm{O}_{3}$ & $<1.15$ & $<0.35$ & $<0.35$ \\
$\mathrm{TiO}_{2}$ & $<0.35$ & $<0.12$ & $<0.06$ \\
\hline
\end{tabular}

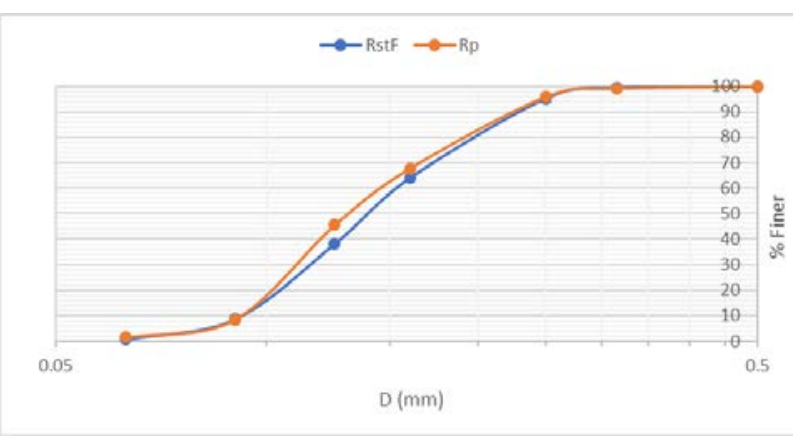

Figure 5: Particle size distribution - Rp and RstF.

Slika 5: Zrnavostna sestava - Pp in RstF.

Effective grain size $\mathrm{D}_{10}$ of sand produced at the Ravno location is 0.092 for both qualities RstF and $\mathrm{Rp}$, with the coefficients of uniformity of 1.70 and 1.61, respectively (obtained from the particle size distribution curve shown in Figure 5). At the moment, most of the sand produced at the location is intended for special, fireproof, and refractory masses, as well as silica brick production. In the past, it was also used as a raw material for glass and glass mineral wool production. Other and new applications could be considered and examined, based on the quartz sand properties described, as the market opportunities and demands change. Quartz sand from the location might be prominent for use in filtration membrane production, based on the comparison with studies made by other authors (Aloulou et al., 2017; Ivanets and Agabekov, 2017). Quartz sand from Ravno has a higher $\mathrm{SiO}_{2}$ content than the one used in Aloulou et al. (2017), as well as particle size distribution uniting sizes for a support layer and microfiltration layer. With more than $90 \%$ of material finer than $0.1 \mathrm{~mm}$, it has high potential in green infrastructure used for water recycling.

\section{Conclusions}

As the most abundant mineral in the Earth's crust, quartz has many uses. Quartz or silica sand use is very diverse, ranging from industrial processes like glass production, or in foundries for e.g. coated sand used in the Croning process for cast iron, aluminium, non-ferrous metals, and cast steel. In civil engineering, quartz sand is used for many materials, such as pavers, mortar, and concrete, and for processes such as sandblasting. Quartz sand is also used for sports fields, including football pitches, golf courses, tennis courts, beach volleyballs, etc.; it is an important material for sport infrastructure. Also, playgrounds and sand boxes make use of quartz sand. In addition to conventional uses, it shows potential in recently emerging areas of applications, such as green infrastructure construction or ceramic membrane production. It is highly prominent for use in water treatment in urban areas and developing countries facing scarce and low-grade water supplies. Such systems could use locally available quartz sand, as it is ubiquitous and relatively easily to process. In determination of its feasibility in any filtering system, particle size distribution of sand (or gravel) seems to be the most important property. To precisely determine its potential use, all of its properties must be examined and determined in detail, and preferentially be accordant to a norm (if existing). Green infrastructure is still emerging for sanitary and water engineering in practice. Wider use and public acceptance of green infrastructure could play a big role in mitigating water scarcity and slowing environmental change. Even with several commercial manufacturers of such solutions in Slovenia, urban green infrastructure must still be commonly accepted as a part of sustainable 
Kuzmanić T., Mikoš M.: Quartz Sand Use in Hydraulic and Sanitary Engineering - Kremenov pesek v hidrotehniki in

infrastructure. The described quartz sand applications herein are the best available management practices leaning towards sustainability have prospects for capacity building.

\section{Acknowledgments}

We thank the Kremen Group from Novo Mesto for allowing us to review their documentation.

This research was funded by the Slovenian Research Agency, a PhD grant for the first author, and research core funding No. P2-0180.

\section{References}

Abdel-Shafy, H.I., El-Khateeb, M.A., Shehata, M. (2014). Greywater treatment using different designs of sand filters. Desalination and Water Treatment 52, 52375245. https://doi.org/10.1080/19443994.2013.813007.

Aloulou H., Bouhamed H., Amar R.B., Khemakhem S. (2017). New ceramic microfiltration membrane from Tunisian natural sand: application for tangential wastewater treatment. Desalination and Water Treatment 78, 41-48. https://doi.org/10.5004/dwt.2017.20921.

Balbay, S. (2019). Recycling of waste foundry sands by chemical washing method. China Foundry 16 (2) 141146. https://doi.org/10.1007/s41230-019-8144-4

Boano, F., Caruso, A., Costamagna, E., Ridolfi, L., Fiore, S., Demichelis, F., Galvao, A., Pisoeiro, J., Rizzo, A., Masi, F. (2020). A review of nature-based solutions for greywater treatment: Applications, hydraulic design, and environmental benefits. Science of the total environment 711. https://doi.org/10.1016/j.scitotenv.2019.134731.

British Geological Survey. (2020). Silica sand: Mineral Planning Factsheet.

Borek, K., Czapik, P., Dachowski, R. (2020). Recycled Glass as a Substitute for Quartz Sand in Silicate Products. Materials 13(5), 1030. https://doi.org/10.3390/ma13051030.

Bradshaw, S.L., Benson, C.H., Olenbush, E.H., Melton, J.S. (2012). Using foundry sand in green infrastructure construction. Green Streets and Highways Conference 2010, ASCE, 280-298. https://doi.org/10.1061/41148(389)24.

Brandt, M.J., Johnson, K.M., Elphinston, A.J., Ratnayaka, D.D. (2017). Twort's Water Supply. 7th Ed. Butterworth-Heinemann, 898 pp.
BS EN 12904:2005 Products used for treatment of water intended for human consumption - silica sand and silica gravel.

Casey, T. J. (2006). Unit Treatment Processes in Water and Wastewater Engineering. Aquavarra Research Limited. Dublin (http://www.aquavarra.ie/Utpbkpdf/chap6.pdf) p.62-77.

Chen, X., Zhang, L. (2019). Treatment of domestic wastewater in biochar-packed tidal flow constructed wetland. Ecol. Environ. Sci. 28 (7), 14431449.https://doi.org/10.16258/j.cnki.16 745906.2019.07.018.

Curran, M. A. (ed.). (2012). Life Cycle Assessment Handbook: A Guide for Environmentally Sustainable Products. Scrivener Publishing. ISBN 978-1-118-099728 pp.611.

Drovenik, M., Pleničar, M., Drovenik, F. (1980). Nastanek rudišč v SR Sloveniji $=$ The origin of Slovenian ore deposits. Geologija 23(1), 1-157. http://www.geologija-revija.si/dokument.aspx?id=492

European Bank for Reconstruction and Development (EBRD). n.a. Sub-sectoral Environmental and Social Guidelines: Stone, Sand and Gravel.

European Union. (2015). Optimising water reuse in the EU: Final report - Part I. doi: 10.2779/603205

European Union. (2020). Circular Economy Action Plan: For a cleaner and more competitive Europe.

Eurostat. (2020a=. Recycling rate of municipal waste. https://ec.europa.eu/eurostat/databrowser/view/t2020_rt $\underline{120 / \text { default/table?lang }=\text { en }}$

Eurostat (2020b). Recycling rate of waste excluding major mineral wastes. https://ec.europa.eu/eurostat/databrowser/view/sdg_12_ 60/default/table?lang=en

Eurostat. (2020c=. Landfill rate of waste excluding major mineral wastes. https://ec.europa.eu/eurostat/databrowser/view/t2020_rt $\underline{110 / \text { default/table?lang }=\text { en }}$

Ferreira, H., Leite, M. G. P. (2015=. A Life Cycle Assessment study of iron ore mining. Journal of Cleaner production $108.1081-1091$. https://doi.org/10.1016/j.jclepro.2015.05.140

Finch, J.A., Wills, B. A. (2016). Wills' Mineral Processing Technology: An Introduction to the Practical Aspects of Ore Treatment and Mineral Recovery. Eighth Edition. Oxford: Elsevier. 
Kuzmanić T., Mikoš M.: Quartz Sand Use in Hydraulic and Sanitary Engineering - Kremenov pesek v hidrotehniki in

Forward, H.S., Hatt, B.E., Breen, P., Cook, P.L.M., Deletic, A. (2017). Designing living walls for greywater treatment. Water research 110, 218-232. https://doi.org/10.1016/j.watres.2016.12.018.

Fuerstenau, M. C., Han K. N. (2003). Principles of mineral processing. Littleton: Society for Mining Metallurgy and Exploration.

Geološki zavod Slovenije. (2019a). Mineralne surovine v letu 2018. Mineralne surovine 15(1), 1-169. https://www.geo-

zs.si/PDF/PeriodicnePublikacije/Bilten_2018.pdf

Geološki zavod Slovenije. (2019b). Karta pridobivalnih prostorov mineralnih surovin s koncesijo v letu 2018 Merilo 1:500.000 (Map of Mineral Extraction Areas with Concession in $2018 \quad-$ Scale 1:500,000). https://www.geo-

zs.si/PDF/PeriodicnePublikacije/Karta_koncesije_2018. pdf

Global Aggregates Information Network GAIN. n.d. GAIN World Map. (https://www.gain.ie/)

Götze, J. (ed.), Möckel, R. (ed.). (2012). Quartz: Deposits, Mineralogy and Analytics. Springer-Verlag Berlin Heidelberg ISBN: 978-3-642-22160-6 eISBN: 978-3-642-22161-3 Doi: 10.1007/978-3-642-22161-3 p. $2-21$.

Götze, J. (2009). Chemistry, textures and physical properties of quartz - geological interpretation and technical application. Mineralogical Magazine 73(4), 645-671. Doi: 10.1180/minmag.2009.073.4.645.

Grbeš, A. (2016). A Life Cycle Assessment of Silica Sand: Comparing the Beneficiation Processes. Sustainability 8(1), 11, https://doi.org/10.3390/su8010011.

Gupta, A., Yan, D. S. (2016). Mineral Processing Design and Operations: An Introduction. Second edition. Oxford: Elsevier.

Hoffmann, H., Platzer, C., Winker, M., von Muench, E. (2011). Technology review of constructed wetlands: Subsurface flow constructed wetlands for greywater and domestic wastewater treatment. Deutsche Gesellschaft für Internationale Zusammenarbeit (GIZ) GmbH. Eschborn.

ITACA. (2005). An Introduction to Slow Sand Filtration. (https://www.itacanet.org/doc-archiveeng/water/Intro_SSF.pdf).

Ivanets A.I., Agabekov V.E. (2017). Ceramic Microfiltration Membranes Based on Natural Silica.
Petroleum Chemistry 57-2, 117-126. https://doi.org/10.1134/S0965544117020037.

Ivanets, A.I., Azarova, T.A., Agabekov, V.E., Azarov, S.M., Batsukh, Ch., Batsuren, D., Prozorovich, V.G., Rat'ko, A.A. (2016). Effect of phase composition of natural quartz raw material on characterization of microfiltration ceramic membranes. Ceramics international 42(2016), 16571-16578. http://dx.doi.org/10.1016/j.ceramint.2016.07.077.

Jenkins, M.W., Tiwari, S.K., Darby, J. (2011). Bacterial, viral and turbidity removal by intermittent slow sand filtration for household use in developing countries: Experimental investigation and modeling. Water research 45, 6227-6239. https://doi.org/10.1016/j.watres.2011.09.022.

Kennedy, B. A. (ed.). (2009). Surface Mining, $2^{\text {nd }}$ Edition. Society for Mining, Metallurgy, and Exploration Inc. ISBN: 978-0-87335-303-8.

Kuzmanić, T. (2018). Gravitacijska koncentracija kremenog pijeska (Gravity concentration of quartz sand). Master's Thesis. University of Zagreb. Faculty of Mining, Geology and Petroleum Engineering. https://urn.nsk.hr/urn:nbn:hr:169:669586

Liu, J., Zhu, X., Zhang, H., Wu, F., Wei, B., Chang, Q. (2018). Superhydrophobic coating on quartz sand filter media for oily wastewater filtration. Colloids and Surfaces 553, 509-514. https://doi.org/10.1016/j.colsurfa.2018.06.007.

Logsdon, G. S. (2008). Water Filtration Practices: including slow sand filters and precoat filtration. American Water Works Association. ISBN 978-158321-595-1 p 71-78.

Lopato, L. R. (2011). Granular filters for water treatment: heterogeneity and diagnostic tools. Technical University of Denmark.

Maiga, Y., von Sperling, M., Mihelcic, J.R. (2017=. Constructed Wetlands. Global water pathogen project: Part four. Management of risk from excreta and wastewater. https://doi.org/10.14321/waterpathogens.66 (http://www.waterpathogens.org).

Mikoš, M. (2017). Rečni sediment in mineralni agregati $\mathrm{v}$ gradbeništvu = Fluvial Sediments and Mineral Construction Aggregates. Gradbeni vestnik 66, 296-306. Available at: http://www.zveza-dgits.si/recni-sedimentiin-mineralni-agregati-v-gradbenistvu

Ministry of natural resources and environment, Department of irrigation and drainage Malaysia (DID). 
Kuzmanić T., Mikoš M.: Quartz Sand Use in Hydraulic and Sanitary Engineering - Kremenov pesek v hidrotehniki in

(2009). River sand mining management guideline. ISBN 978-983-41867-2-2.

Organisation for Economic Co-operation and Development OECD. (2016). Policy Guidance on Resource Efficiency. OECD Publishing, Paris. https://dx.doi.org/10.1787/9789264257344-en.

Organisation for Economic Co-operation and Development OECD. (2019). Global Mineral Resources Outlook to 2060: Economic Drivers and Environmental Consequences. OECD Publishing, Paris. https://doi.org/10.1787/9789264307452-en.

Padmalal, D., Maya, K. (2014). Sand Mining: Environmental Impacts and Selected Case Studies. Springer Science + Business Media Dordrecht. ISBN: 978-94-017-9144-1.

Panjan, J. (2002). Osnove zdravstveno hidrotehnične infrastrukture. Ljubljana, Univerza v Ljubljani, Fakulteta za gradbeništvo in geodezijo. ISBN: 961-6167-48-0 p. 50-52.

Peduzzi, P. (2014). Sand, rarer than one thinks: Article reproduced from United Nations Environment Programme (UNEP) Global Environmental Alert Service (GEAS). Environmental Development 11. 208-218. http://dx.doi.org/10.1016/j.envdev.2014.04.001.

Pettijohn, F.J., Potter, P.E., Siever, R. (1973). Sand and Sandstone. Springer-Verlag Berlin. e-ISBN-13: 978-14615-9974-6.

Platias, S., Vatalis, K.I., Charalampides, G. (2014). Suitability of quartz sand for different industrial applications. Procedia Economics and Finance 14, 491498. https://doi.org/10.1016/S2212-5671(14)00738-2.

Prochaska, C.A., Zouboulis, A.I. (2003). Performance of intermittently operated sand filters: A comparable study, treating wastewater of different origins. Water, Air, and Soil Pollution 147, 367-388. https://doi.org/10.1023/A:1024550000904.

Prodanovic, V., Hatt, B., McCarthy, D., Zhang, K., Deletic, A. (2017). Green walls for greywater reuse: Understanding the role of media on pollutant removal. Ecological Engineering 102, 625-635. https://doi.org/10.1016/j.ecoleng.2017.02.045.

Pryor, E. J. (1965). Mineral Processing. Third edition. Essex: Elsevier applied science publishers LTD.

RIVM. 2016. ReCiPe (2016). A harmonized life cycle impact assessment method at midpoint and endpoint level. Report I: Characterization.
Rudarska knjiga. (2020). Ravno. https://ms.geozs.si/Prostor/Podrobnosti/91 (Mining book).

Saeed, T., Muntaha, S., Rashid, M., Sun, G., Hasnat, A. (2018). Industrial wastewater treatment in constructed wetlands packed with construction materials and agricultural by-products. J Clean Prod 189, 442-453. https://doi.org/10.1016/j.jclepro.2018.04.115

Saeed, T., Yasmin, N., Sun, G., Hasnat, A. (2019). The use of biochar and crushed mortar in treatment wetlands to enhance the removal of nutrients from sewage. Environmental Science and Pollution Research 26, 586599. https://doi.org/10.1007/s11356-018-3637-z

Shen, Y., Zhuang, L., Zhang, J., Fan, J., Yang, T., Sun, S. (2019). A study of ferric-carbon micro-electrolysis process to enhance nitrogen andphosphorus removal efficiency in subsurface-flow constructed wetlands. Chemical Engineering Journal 359, 706-712. https://doi.org/10.1016/j. cej.2018.11.152.

Sparks, T., Chase, G. (2016). Filters and filtration handbook. 6th Ed. Butterworth-Heinemann. 445 pp.

Stephenson, D. (1998). Water supply management. Water science and technology library. Dordrecht. Kluwer Academic Publishers. ISBN: 0-7923-5136-3 p 250-256.

Tatari, K. (2014). Nitrification biokinetics in rapid sand filters for drinking water treatment. DTU Environment.

Teemusk, A., Mander, Ü. (2011). The Influence of Green Roofs on Runoff Water Quality: A Case Study from Estonia. The Water Resources Management 25, 3699. https://doi.org/10.1007/s11269-011-9877-z.

The Silica and Moulding Sands Association (Samsa), n.a. Silica, Economic importance (https://www.samsa.org.uk/silica/economic importance. php).

Torrens, A., Molle, P., Boutin, C., Salgot, M. (2009). Removal of bacterial and viral indicators in vertical flow constructed wetlands and intermittent sand filters. Desalination 246, 169-178. https://doi.org/10.1016/j.desal.2008.03.050.

Torres, A., Brandt, J., Lear, K., Liu, J. (2017). A looming tragedy of the sand commons. Science 357 (6355), 970971. https://doi.org/10.1126/science.aao0503.

UNEP. (2004). Why Take A Life Cycle Approach. ISBN: 92-807-24500-9

UNEP. (2019). Sand and sustainability: Finding new solutions for environmental governance of global sand resources. GRID-Geneva, United Nations Environment 
Programme, Geneva, Switzerland. ISBN: 978-92-8073751-6.

Vrkljan, D. (2011). Kremeni pijesci. Tehnologija nemetalnih mineralnih sirovina: interna skripta. (Quartz sands. Technology of nonmetallic raw materials: internal script) Zagreb: Rudarsko-geološko-naftni fakultet, Sveučilište u Zagrebu (in Croatian).

Wang, H., Xu, J., Sheng, L. (2020). Preparation of straw biochar and application of constructed wetland in China: A review. Journal of Cleaner Production 273, 123131. https://doi.org/10.1016/j.jclepro.2020.123131.

World Health Organization. (2002). Managing Water in the Home: Accelerated Health Gains from Improved Water Supply.
Yang, Y., Wang, Z.M., Liu, C., Guo, X.C. (2012). Enhanced $\mathrm{P}, \mathrm{N}$ and $\mathrm{C}$ removal from domestic wastewater using constructed wetland employing construction solid waste (CSW) as main substrate. Water Sci Technol 66(5), 1022-1028. https://doi.org/10.2166/wst.2012.277

Wang, Z., Wang, W., Zhu, X., Wang, J., Han, Z., Hua, Y. (2014). Adsorption-Desorption Characteristics of E.coli by Quartz Sands of Different Particle Size. Advanced Materials Research 955-959, 436-444. https://doi.org/10.4028/www.scientific.net/AMR.955$\underline{959.436}$

Žmavčič, M. (1991). Kremenove surovine ter nahajališča, uporaba in raziskave kremenovih surovin. (Quartz raw materials and deposits, use and research). Novo Mesto: Industrija in rudniki nekovin Kremen Novo Mesto (in Slovene). 